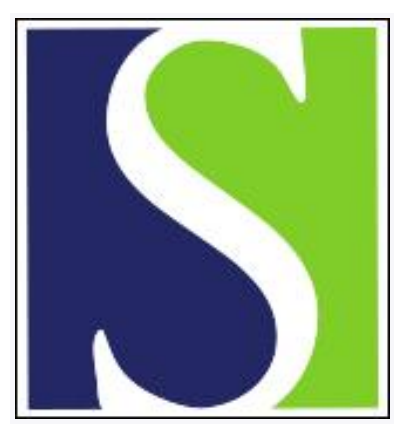

Scand J Work Environ Health 1984;10(3):207

https://doi.org/10.5271/sjweh.2343

Issue date: Jun 1984

Mortality and morbidity of Swedish insulation workers.

by Sanden A, Jarvholm B, Naslund PE

This article in PubMed: www.ncbi.nlm.nih.gov/pubmed/6474114

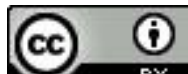




\section{Mortality and morbidity of Swedish insulation workers}

The harmful effects of asbestos are well known, but there are few reports from the Scandinavian countries concerning the risk of asbestos-exposed populations. Petersen \& Venstrup-Nielsen (3) investigated the mortality of male insulation workers in Denmark in 1970-1975. They studied 953 persons who stated that they were insulation workers in the Danish population census in 1970. They found five cases of lung cancer versus 2.1 expected and four cases of tumors of the pleura or mediastinum (3). The objective of our study was to estimate the mortality of asbestosrelated diseases among Swedish insulation workers.

From the trade union of insulation workers in Göteborg we received a list of all active members in 1970. Those who had changed jobs or retired more than two to three years earlier were not included. The list contained 272 individuals, all men. Cancer morbidity and mortality for this group was observed between 1970 and 1979, and there was no loss to follow up. The Cancer Register was scrutinized for the morbidity from cancer. The expected number of cancer cases was calculated from incidence rates of the city of Göteborg and mortality from national incidence rates. The incidence rates were multiplied with the person-years of observation, stratified for age (five-year age classes) and calendar year and summarized over the entire cohort. There was a total of 2,590.5 person-years.

We found 21 deaths versus 17.2 expected. According to the classification on the death certificates there were five deaths from lung cancer [International Classification of Diseases (ICD) 8:162 ] versus $0.8 \mathrm{ex}$ pected and two deaths from asbestosis (ICD 8:515.2).

In the Cancer Register 11 cases of cancer were found versus 7.8 expected. Of these 11 cases three were located in the lung versus 1.1 expected. Another two cases of lung cancer were observed on the death certificates. The medical records of these two cases were reviewed. Both died of lung cancer, and one should have been reported to the Cancer Registry. The other had received his diagnosis abroad and died there, and for such cases there is no imperative reporting to the Cancer Registry. At the time of diagnosis the lung cancer patients were $31,53,64,65$, and 69 years of age.

Three peritoneal mesotheliomas (ICD 8:158) were found, but none in the pleura. There were two cases of pancreatic cancer (ICD 8:157) which had been reviewed by a trained pathologist. One of the pancreas cancers was, after histological examination, reclassified as a peritoneal mesothelioma. The cases with peritoneal mesothelioma were $53,54,64$, and 73 years of age.
In comparison to the number of lung cancers there seemed to be a very high incidence of peritoneal mesothelioma among these insulation workers. The ratios of peritoneal mesothelioma:all deaths were 5:122; 2:46; and 112:2,271 in three other studies of insulation workers $(1,2,4)$ in comparison to $3: 21$ in our study, according to the diagnosis of the registries and the additional case found in the review of the pancreas cancers. This variation may be due to the small numbers in our study, but there might also be undiagnosed cases of peritoneal mesothelioma in the other studies as the diagnosis is very difficult to establish. In the studies mentioned the ratio lung cancer:all deaths was $35: 122 ; 10: 46$; and 486:2,271, ie, values of the same size as in our study ( 5 deaths from lung cancer versus 21 deaths from all causes).

The insulation workers were hired for special jobs in shipyards and the building industry. In the shipyards they mostly sprayed amosite. On a few naval ships crocidolite was used. We have no information on smoking habits, exposure time, or latency period, but this study indicates that the risk of asbestosrelated diseases is similar for Swedish insulation workers and insulation workers in other countries.

\section{Acknowledgments}

This study would not have been possible without the great support of $\mathrm{Mr} \mathrm{N}$ Andersson, former chairman of the insulation workers trade union in Göteborg. We also thank Mr L Steen for his help in establishing the cohort and Professor L Zettergren for reexamining the biopsies.

\section{References}

1. Elmes PC, Simpson MJC. Insulation workers in Belfast: A further study of mortality due to asbestos exposure (1940-1975). Br J Ind Med 34 (1979) 174-180.

2. Kleinfeld M, Messite J, Kooyman O. Mortality experience in a group of asbestos workers. Arch Environ Health 15 (1967) 177-180.

3. Petersen R, Venstrup-Nielsen SE. Dödlighed blandt danske isoleringsarbejdere 1970-75. Ugeskr Laeg 144 (1982) $967-970$.

4. Selikoff IJ, Hammond EC, Seidman H. Mortality experience of insulation workers in United States and Canada 1943-76. Ann NY Acad Sci 330 (1979) $91-116$.

Åke Sandén, MD, ${ }^{1}$ Bengt Järvholm, MD,${ }^{2}$ Per-Erik Näslund, $\mathrm{MD}^{1}$

Götaverken Företagshälsovård $\mathrm{AB}$, Box 8713, S-402 75 Göteborg, Sweden.

2 Department of Occupational Medicine, Sahlgren's Hospital, St Sigfridsgatan 85, S-412 66 Göteborg, Sweden. 


\section{Recordkeeping on occupational exposures and cancer}

Table 1. Asbestos dust concentration associated with the removal of sprayed crocidolite. [These data have been taken from Harries (1).]

\begin{tabular}{|c|c|c|c|c|c|c|}
\hline & \multicolumn{6}{|c|}{ Sample locationa } \\
\hline & $\begin{array}{l}\text { Deck } 7 \\
\text { stripping } \\
\text { area }\end{array}$ & $\begin{array}{c}\text { Hatchway } \\
\text { of deck } 6 \\
\text { leading } \\
\text { from } \\
\text { deck } 7\end{array}$ & $\begin{array}{c}\text { Hatchway } \\
\text { of deck } 5 \\
\text { leading } \\
\text { from } \\
\text { deck } 6\end{array}$ & $\begin{array}{c}\text { Passage- } \\
\text { way to } \\
\text { shower }\end{array}$ & $\begin{array}{l}\text { During } \\
\text { removal } \\
\text { of suits } \\
\text { after } \\
\text { shower }\end{array}$ & $\begin{array}{l}\text { Workmen's } \\
\text { dining } \\
\text { room }\end{array}$ \\
\hline $\begin{array}{l}\text { Asbestos concentration } \\
\left.\text { (fibers } / \mathrm{cm}^{3}\right)\end{array}$ & 311 & 109 & 30 & 25 & 16 & 0.05 \\
\hline
\end{tabular}

a Long-running Hunt samplers were used.

Occupational exposure registers are proliferating. Some for well-defined needs, some just for recordkeeping in case someone may need the data one day. Whatever the case, the data to be stored must be well defined, and, in doing so, one has to make a choice considering the complexity of the information and the need for output. Exposure to carcinogens presents a problem of its own. Let me give some examples.

Registers are not established for known but for not proven or unknown carcinogens. Such a register will become useful 10-40 years from now. During the same time, the intensive research on "in vitro" and "in vivo" tests may have sorted out the strong carcinogens. What is left will possibly be weak carcinogens that give rise to a few extra cancers. Standardized mortality ratios (SMR) can then only be determined with wide confidence intervals. In any model with a curvilinear relationship between SMR and total dose this situation will imply that the precision in determining the dose need not be great. Knowledge of length of employment and of whether a substance is present or not may suffice.

One can only store data on concentrations and work processes that have been monitored. This problem is probably the greatest restriction in the usefulness of an exposure register. The complexities one may encounter has been illustrated for the rubber industry (2).

The apparently simple problem of relating data on man-made mineral fiber exposure and cancer mortality, etc, has led to intensive fiber concentration measurements since 1976. It is now an open question whether other substances should have been monitored. At present, efforts are being made to determine past uses of oils, binders, etc (W Linander, personal communication).

Unknown exposure to known carcinogens, ie, bystanders' exposure, is also a problem. The now classical asbestos fiber measurements during delagging on board ships (1) clearly show the importance of the problem (table 1). Other solid or liquid carcinogens may spread in a similar manner.
Suppose that over the years air samples have been taken and analyzed for some specified components. If it later turns out that another component is relevant, it will then be possible to extrapolate from an analyzed to a nonanalyzed or nonsampled component. In order to evaluate the problem, my colleagues and I have analyzed our exposure data for industrial spray painters. It turned out, not very surprisingly, that the exposures varied. However, the betweenplant variation in the relative concentration of three chosen solvents (toluene, xylene, and ethanol) was as large as their within-plant variation. This finding indicates that it is as important to know the composition of the materials used as it is to know some of the actual exposures when the exposure for a whole occupational group is being characterized.

I think that all these examples point in one direction regarding recordkeeping on occupational exposure and cancer. What is needed is a register of the actual users of chemical substances and materials. This type of information is needed before priorities can be set for improving conditions for work with chemical substances and materials of all types, and to establish a register, if only for that reason, is worth the effort. As a spin-off, such a register can be used in the future for linkage with cancer registers.

\section{References}

1. Harries PG. Asbestos dust concentration in ship repairing: A practical approach to improving asbestos hygiene in naval dockyards. Ann Occup Hyg 14 (1971) $241-254$.

2. Spiegelhalder B. Carcinogens in the workroom air in the rubber industry. Scand J Work Environ Health 9 (1983): suppl 2, 15-25.

Thomas Schneider, MSc

Danish National Institute of Occupational Health

Baunegaardsvej 73

DK-2900 Hellerup, Denmark 